\title{
Quantitative analytical hierarchy process to marketing store location selection
}

\author{
Harwati $^{*}$ and Intan Utami \\ Industrial Engineering Department, Universitas Islam Indonesia, 55501, Yogyakarta
}

\begin{abstract}
The selection of Store to market the product is belong to Multi Criteria Decision Making problem. The criteria used have conflict of interest with each other to produce an optimal location. This research uses four important criteria to select new location of marketing store appropriate with the references: distance to location, competition level with competitor, number of potential customer, and location rent cost. Quantitative data is used to determine the optimum location with AHP method. Quantitative data are preferred to avoid inconsistency when using expert opinion. The AHP result optimum location among three alternatives places.
\end{abstract}

\section{Introduction}

Marketing is one of the keys to success to realize the goals of the company, especially in increasing the value of sales followed by increased profits. A strong marketing capability of a firm provides communication and promotion of a product in the commercialization [9]. One effective marketing strategy is to expand the marketing area. Location is often regarded as trivial, but the location of the business largely determines business strategic planning and operational profit [6]. Location selection should also refer to the development of an area. Both positive and negative impacts can affect performance and business development. The location selection is one of critical decision of distribution network and it is belong to a multi-criteria decision making (MCDM) problem [4]. As one of the problems of MCDM, the location consists of various criteria that are considered in choosing the best alternative from several alternatives. There are several criteria commonly used as a consideration of location selection. It is said that the decision making of location selection is influenced by many factors, such as the impact of resources, population, transportation, education, the level of development of industry, consumption levels, government policies and other factors affected the region, the impact of the economic activity and production processes [2]. It is also said that from his literature review it is indicated that there are four aspect to select best location: Economic Impacts i.e. less cost, functional impacts i.e. higher productivity, public acceptance i.e. better community relations, and quality of life i.e. better living conditions [8]. Even, a researcher was suggested parking facilities and located at a street corner to be criteria in location selection [7]. Conflict between criteria has become one of the features in MCDM problems. There are many methods successfully formulated to solve this MCDM problem. ELEKTRE, SAW, TOPSIS, AHP, ANP, BWM are some method that usually used to solve the MCDM problems. Fuzzy SAW was used to select facility location [10]. TOPSIS combined with AHP is used to select join distribution center location [11]. Determination of emergency logistic locations can be also done by MCDM method which is in this case uses AHP [5].

Expert opinion is usually used to compare the degree of importance among criteria. Opinions are subjective so it is possible to inconsistent [1]. This paper focus on selection of distribution location using quantitative data. Quantitative data is used partially to compare alternatives in each criteria. The use of this technique is expected to minimize the bias that occurs when using expert judgment.

\section{Case Study}

This study aims to determine the optimal location among three alternatives of locations for marketing traditional canned food PT X. PT X is a famous traditional canned food factory in Yogyakarta. The problem firstly identified when the sales rate did not reach the target. The company has targeted sales of 6000-8000 cans per month or 180240 mil IDR but the amount sold was only 3000-4000 or worth with only 90-120 mil IDR per month. PT X wanted to open another branch of the store to increase product sales. There are three alternative places of marketing that match with the purpose of making the product as souvenirs: airport, train station and bus station. The location of each alternatives places comparing with the factory is presented in the figure 1 .

Based on previous literature, the criteria which are commonly used on store selection decision for marketing stores have been studied by various number of research. There are many criteria which are importantly influence the selection location decision. Distance, from factory or manufacturer to the store, has been determined as one of factors to select location (et al). Distance will affect the

\footnotetext{
*Corresponding author: harwati@uii.ac.id
} 
manufacturer's access to the selected store. To get optimum decision in location selection, many researchers also consider competition level and potential customer. Competition level can be represented by number of competitor's store in the location. Store selection is also influenced by the sellers desire to reach as many consumers as possible (Akalin, et al 2013). That is why the number of potential customer is also considered to be criterion in store location. Store selection should also consider the costs include the costs to buy or rent, renovation costs, and store set up costs (Irwing, 1987). So, in this case study there are four criteria and three alternatives to find the optimum location. That system can be presented is the hierarchy structure as shown in figure 2.

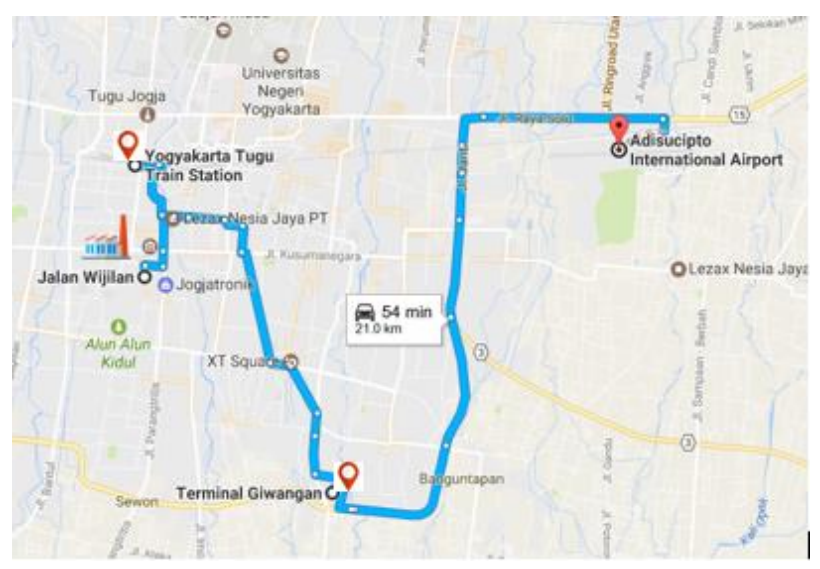

Fig. 1. Map of case study location

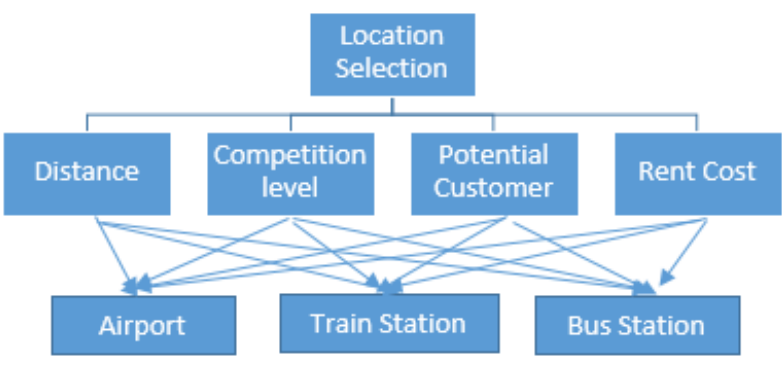

Fig. 2. Hierarchy structure of location selection case

\subsection{Data Collection}

The first step in the calculation is to define the definitions and perspectives for each of the criteria. Description of each criteria related to the case study is shown in the Table 1.

To collect quantitative data for each criteria we used primary and secondary survey. Distance between factories to each location is calculated from the fastest route in Google Map. This calculation ignores the jam and other disruption that may happen on the way. The result is shown in the Table 2.
Table 1. Criteria description

\begin{tabular}{|l|l|}
\hline Criteria & Description \\
\hline Distance & $\begin{array}{l}\text { Distance between Factory to } \\
\text { each location }\end{array}$ \\
\hline Competition Level & $\begin{array}{l}\text { Number of competitor store in } \\
\text { location }\end{array}$ \\
\hline Potential Customer & Number of passenger \\
\hline Cost & Rent cost \\
\hline
\end{tabular}

Table 2. Duration from factory to location

\begin{tabular}{|l|l|}
\hline From Factory to & Duration \\
\hline Airport & 29 minutes \\
\hline Train Station & 7 minutes \\
\hline Bus Station & 18 minutes \\
\hline
\end{tabular}

Number of competitors are counted from the number of stores that sell similar products in each location. The result is shown in the Table 3.

Table 3. Number of Competitors

\begin{tabular}{|l|l|}
\hline Location & Competitors \\
\hline Airport & 3 stores \\
\hline Train Station & 5 stores \\
\hline Bus Station & 13 stores \\
\hline
\end{tabular}

Potential customer is counted from number of passenger arrival in a month. The result is shown in the Table 4.

Table 4. Number of passengers

\begin{tabular}{|l|l|}
\hline Location & Passengers \\
\hline Airport & 633.638 \\
\hline Train Station & 246.111 \\
\hline Bus Station & 228.432 \\
\hline
\end{tabular}

Assuming there is no new location development, all alternative locations will be leased from the transport facility management, then this following data for rental price per $\mathrm{m}^{2}$ per month for each location:

Table 5. Rental cost

\begin{tabular}{|l|l|}
\hline Location & Cost \\
\hline Airport & 200.000 \\
\hline Train Station & 62.500 \\
\hline Bus Station & 49.500 \\
\hline
\end{tabular}

\subsection{Pairwise Comparison}

Based on quantitative data above, then pairwise comparison is compiled to show the importance of an alternative to others. The following are presented pairwise comparison data for each alternative: 
Table 6. Duration pairwise comparison

\begin{tabular}{lccc}
\hline Alternatives & Airport & $\begin{array}{c}\text { Train } \\
\text { Station }\end{array}$ & $\begin{array}{c}\text { Bus } \\
\text { Station }\end{array}$ \\
\hline Airport & 1 & $29 / 18$ & $7 / 18$ \\
\hline Train Station & $18 / 29$ & 1 & $7 / 29$ \\
\hline Bus Station & $18 / 7$ & $29 / 7$ & 1 \\
\hline
\end{tabular}

Table 7. Duration pairwise comparison

\begin{tabular}{lccc}
\hline Alternatives & Airport & $\begin{array}{l}\text { Train } \\
\text { Station }\end{array}$ & $\begin{array}{l}\text { Bus } \\
\text { Station }\end{array}$ \\
\hline Airport & 1 & $3 / 13$ & $5 / 13$ \\
\hline Train Station & $13 / 3$ & 1 & $5 / 3$ \\
\hline Bus Station & $13 / 5$ & $3 / 5$ & 1 \\
\hline
\end{tabular}

Table 8. Duration pairwise comparison

\begin{tabular}{lccc}
\hline $\begin{array}{l}\text { Alternati } \\
\text { ves }\end{array}$ & Airport & Train Station & Bus Station \\
\hline Airport & 1 & $\begin{array}{c}246.111 / 633 . \\
838\end{array}$ & $\begin{array}{c}228.342 / 633 . \\
838\end{array}$ \\
\hline Train & $633.838 / 246$. & 1 & $228.342 / 246$. \\
Station & 111 & & 111 \\
\hline Bus & $633.838 / 228$. & $246.111 / 228$. & 1 \\
Station & 342 & 342 & \\
\hline
\end{tabular}

Table 9. Duration pairwise comparison

\begin{tabular}{lccc}
\hline $\begin{array}{l}\text { Alternativ } \\
\text { es }\end{array}$ & Airport & Train Station & Bus Station \\
\hline Airport & 1 & $\begin{array}{c}200.000 / 62.5 \\
00\end{array}$ & $\begin{array}{c}200.000 / 49.5 \\
00\end{array}$ \\
\hline Train & $62.500 / 200.0$ & 1 & $62.500 / 49.50$ \\
Station & 00 & & 0 \\
\hline Bus & $45.900 / 200.0$ & $62.500 / 49.50$ & 1 \\
Station & 00 & 0 &
\end{tabular}

\subsection{Consistency Testing}

Pairwise comparison for criteria level is done by asking judgement from owner to compare criteria each other depend on their interest. Before calculating the weight of each alternative, consistency testing is done on each criteria comparison. This step is necessary to be done to see the consistency of quantitative data obtained. The result of the consistency testing is shown as the Table 10.

From the Table 10, it is known that the most importance criteria according to owner judgement is distance with percentage $33 \%$ followed by competition level $23 \%$; potential customer $24 \%$ and rent cost $19 \%$. Since the consistency ratio is more than 0.1 (in this case the consistency ratio is 0.18 ) it is recommended to query the comparison between these criteria. The rest of consistency testing result for each alternatives in every criteria is shown in the Table 11.
Table 10. Matrix comparison for main criteria, degree of importance, and consistency ratio

\begin{tabular}{|c|c|c|c|}
\hline Criteria & Distance & $\begin{array}{l}\text { Competition } \\
\text { Level }\end{array}$ & \\
\hline Distance & 1 & 2 & \\
\hline $\begin{array}{l}\text { Competition } \\
\text { Level }\end{array}$ & $1 / 2$ & 1 & \\
\hline $\begin{array}{l}\text { Potential } \\
\text { Customer }\end{array}$ & $1 / 2$ & $1 / 2$ & \\
\hline Cost & 1 & 1 & \\
\hline Criteria & $\begin{array}{l}\text { Potential } \\
\text { Customer }\end{array}$ & Cost & $\begin{array}{l}\text { Degree of } \\
\text { Importance }\end{array}$ \\
\hline Distance & 1 & 2 & 0,330 \\
\hline $\begin{array}{l}\text { Competition } \\
\text { Level }\end{array}$ & $1 / 2$ & 1 & 0,233 \\
\hline $\begin{array}{l}\text { Potential } \\
\text { Customer }\end{array}$ & $1 / 2$ & $1 / 2$ & 0,241 \\
\hline Cost & 1 & 1 & 0,196 \\
\hline $\mathrm{CR}$ & & & 0.18 \\
\hline
\end{tabular}

Table 11. Criteria description

\begin{tabular}{|l|c|c|c|c|}
\hline \multirow{2}{*}{ Alternatives } & \multicolumn{4}{|c|}{ Degree of Importance } \\
\cline { 2 - 5 } & Distance & $\begin{array}{l}\text { Competition } \\
\text { Level }\end{array}$ & $\begin{array}{l}\text { Potential } \\
\text { Customer }\end{array}$ & Cost \\
\hline Airport & 0.149 & 0.126 & 0.157 & 0.117 \\
\hline $\begin{array}{l}\text { Train } \\
\text { Station }\end{array}$ & 0.606 & 0.546 & 0.405 & 0.385 \\
\hline Bus Station & 0.245 & 0.328 & 0.437 & 0.498 \\
\hline CR & 0 & 0 & 0 & 0 \\
\hline
\end{tabular}

\section{Result and Discussion}

The calculation of weighted alternatives is done by summing the value of each alternative based on each criterion, so that the AHP result is as follows

Table 12. AHP result

\begin{tabular}{|l|c|c|}
\hline Alternatives & Weight & Ranking \\
\hline Airport & 0.20 & 3 \\
\hline Train Station & 0.35 & 2 \\
\hline Bus Station & 0.44 & 1 \\
\hline
\end{tabular}

Based on the previous calculation we get the weight of each alternative according to the location access that Train Station has the highest weight of 0.606 , then Bus Station has a weight of 0.245 and the last is Airport with a weight of 0.149 . The easier access to a location, the lower the cost of transportation. Otherwise, the more difficult access to a location, the higher the cost of transportation. Based on the level of competition, train station is also the best alternative (weight 0.546) due to low number of sellers with the same type of product. The lower competition number in the same location, the more people who probably buy in the area, and the more competitors of the same product in that location, the less people will buy That means, the lower the level of competition, the higher the chances of the company in selling its products. Based on level of crowd, it is resulted that bus station is the best alternative. The more crowded a location then the more chances of people who do shopping at that location. Otherwise, the more lonely a location will be the lower 
the chances of people shopping at that location. This will affect the company's sales volume. The calculation of the weight of each location based rental price obtained that the Bus Station with weight 0.495 is suitable to be the location of business. The more costs the company incurs, the higher the sacrifices the company makes for that location.

With the calculation of AHP method, the weight of each alternative in terms of the overall criteria is as follows: (1) Train Station with percentage 49.8\% (2) Airport with percentage $38.5 \%$ and (3) Bus Station with percentage $11.7 \%$. This indicates that the alternative location 3 or Bus Station is the best location to be the location of the new marketing branch when viewed from the criteria of location access, the level of competition, potential customer, and the rental cost.

Overall, the best alternative to build new location of product marketing facility is in train station. In determining this location, many criteria should be used as decision-making factors. But very few criteria that can be obtained from quantitative data. This study only focuses on quantitative data, therefore qualitative data such as questionnaires or public opinion are not included in this study. In addition, the authors have not considered or separated the criteria into two types, namely positive criteria and negative criteria. The problem structure in this study is in still single hierarchy and not considered in the relationship or interconnection among sub criteria. The main advantages of problem solving using a hierarchical structure are easier to do and more quickly get a decision

\section{References}

1. Arto Haaraa, Ron Store, Pekka Leskinen, 2017, Analyzing Uncertainties And Estimating Priorities Of Landscape Sensitivity Based On Expert Opinions, Landscape and Urban Planning 163, 56-66

2. H. S. Lei and Y. S. Chen, "The right tree for the right bird: Location choice decision of Taiwanese firms ${ }^{\text {ee }}$ FDI in China and Vietnam," International Business Review, vol. 20, pp. 338-352, 2011

3. Irwing, B. (1986). Basic retailing. Irwin, Inc. Illinois, USA
4. J. Raymond and J. Mataloni, "The structure of location choice for new U.S. manufacturing investments in Asia-Pacific," Journal of World Business, vol. 46, no. 2, pp. 154-165, 2004

5. Liu Hong, Zhang Xiaohua, 2011, Study on location selection of multi-objective emergency logistics center based on AHP, Procedia Engineering, Volume 15, Pages 2128-2132

6. Liu, Weng-Kun, 2015, Using FDM and DEMATEL Approaches to Evaluate the Location Selection of Investment, International Journal of Information and Education Technology; Vol. 5, No. 10, p: $732-739$

7. Mehmet Akalin, Gulden Turhan, Azize Sahin. (2013). The Application of AHP Approach for Evaluating Location Selection Elements for Retail Store: A Case of Clothing Store, International Journal of Research in Business and Social Science, IJRBS Vol.2 No.4

8. Mahalik, Debendra Kumar, (2012), Selection of a Plant Site: A Multi Criteria Decision Making Using AHP and GRA, Journal of Supply Chain Management Systems; No 1 Vol 4, p: 23-29.

9. Nanwoon Kim, Sohyoun Shin, Sungwok Min, 2016, Strategic Marketing Capability: Mobilizing Technological Resources For New Product Advantage, Journal of Business Research, Volume 69, Issue 12, Pages 5644-5652

10. Shuo-Yan Chou. Yao-HuiChang, ChunYingShen,(2008) A Fuzzy Simple Additive Weighting System Under Group Decision-Making For Facility Location Selection With Objective/Subjective Attributes, European Journal of Operational Research, Volume 189, Issue 1, Pages 132-145

11. Yandong He, Xu Wang, Yun Lin, Fuli Zhou, Lin Zhou, (2017), Sustainable Decision Making For Joint Distribution Center Location Choice, Transportation Research Part D 55 202-216. 